\title{
Analysis of Financial Statements to Assess Financial Performance in Plantation Sub-Sector Companies Registered in Indonesian Stock Exchange
}

\author{
Sasmito Widi Nugroho ${ }^{1}$, La Ode Abdullah ${ }^{2}$, Nova Maulud Widod ${ }^{3}$, Rois Septi Aulia ${ }^{4}$ \\ State Polytechnic of Madiun, Jl. Serayu No. 84, Madiun, East Java 63131, Indonesia ${ }^{1,2,3,4}$ \\ $\left\{\right.$ why21dhi@yahoo.com $\left.{ }^{1}\right\}$
}

\begin{abstract}
Plantation sub-sector companies have a significant contribution to the Indonesian economy. The plantation sub-sector companies is one of the mainstay sub-sectors in contributing forreign exchange, because it has a high export market orientation. The study aims to find out how the financial performance of plantation sub-sector companies listed on Indonesian Stock Exchange for period 2017-2019. The data use in this study are secondary data in form of financial statements for the period 2017-2019. The method use in this study use ratio analysis, trend analysis, and common size analysis in plantation sub-sector companies listed on the Indonesia Stock Exchange. The data analysis technique use starts from data collection, problem analysis, comparing data, analysis data, assesing performance, and drawing conclusions. The results of the analysis of the financial ratios of plantation companies listed on the IDX in 2017-2019 allow liquidation levels using the current ratio, some are in the good category and some are in the bad category. Most of the debt ratio analysis is in the poor category and only as good as the small ones are in the good category. Accounts receivable turnover analysis as good as possible is in the good category. The results of the analysis of trends in the financial statements for 2017-2019 show that almost all companies experience an increasing trend every year. The results of the analysis of the general size of the plantation companies listed on the IDX 2017-2019 mostly have a good level of similarity
\end{abstract}

Keywords: Financial Performance, Ratio Analysis, Common Size Analysis, Company Plantation Sub Sector

\section{Introduction}

This is Financial statements are the final result of a process of recording financial transactions that occur during the company's financial year. Financial statements are part of the financial reporting process. Analysis of the company's financial statements will be very helpful in assessing management achievements in the past and can provide a real picture of the results or achievements that have been achieved by a company during a certain period of time. Information regarding the company's financial performance provides benefits to investors, 
creditors, government, banks, company management and parties with an interest in the company.

The object of this research is plantation companies that have been listed on the Indonesia Stock Exchange. Researchers use plantation companies as research objects because plantation companies are companies that have a strategic role to the community. Plantation companies also play a role in providing employment in rural areas, economic growth, environmental conservation.

Based on the background above, the problem formulations in this study are:

a) How to analyze financial ratios, which include liquidity, solvency, activity, and probability, to assess the financial performance of plantation companies listed on the Indonesia Stock Exchange

b) How is trend analysis and common size analysis to assess the financial performance of plantation companies listed on the Indonesia Stock Exchange

Therefore, researchers are interested in conducting research with the title "Analysis of Financial Statements to Assess Financial Performance in Plantation Sub-Sector Companies Registered in Indonesian Stock Exchange".

\section{Theory}

\subsection{Financial Report}

Sadeli states that the purpose of financial statements is the final product of the accounting activity process of a business entity. This report is required by interested parties, including: company managers, company owners, creditors, investors, governments, and other parties with an interest in the company [1][2]. Financial reports must be prepared properly to meet the needs of all parties. financial statements like this are called general purpose financial statements. General purpose, financial statements are as follows [3][4].

\subsection{Financial Report Components}

SAK number 1 paragraph 9 states that the components of a complete financial report consist of:

a) Statement of financial position at the end of the period

b) Statements of profit or loss and other comprehensive income during the period

c) Change in equity report

d) Cash flow statement during the period

e) Notes to financial statements

\subsection{Plantation Companies}

The Central Statistics Agency states that plantation companies are companies in the form of business entities / legal entities engaged in the cultivation of plantation crops on land that is controlled, for economic purposes and obtaining a business license from the authorized agency in granting plantation businesses.

Plantation companies try to process their garden products into finished, or semi-finished goods, in the hope of obtaining high economic value. A nucleus garden is a garden that is built by a plantation company with complete processing facilities owned by the plantation company 
and is prepared to become the executor of the people's nucleus plantation. A plasma plantation is a garden that is built and developed by a company. Since planting, this garden has been managed by the nucleus plantation until it is producing. After the plants start producing, the control is handed over to the community or garden farmers.

\subsection{Financial Report}

Hery financial statement analysis is a method to help decision makers to find out the strengths and weaknesses of the company through information obtained from financial reports. Financial statement analysis can help management to identify deficiencies in the company, then make decisions to improve company performance. Financial statement analysis is also useful for investors and creditors to make decisions [5]. Hery states that the objectives and benefits of conducting financial statement analysis are[6]:

a) To find out the company's financial position in a certain period, whether it is assets, liabilities, equity or business results that have been achieved

b) To assess management performance

c) Knowing the weaknesses of the company

d) Knowing the strengths that are the advantages of the company

e) Determine the corrective steps that need to be done in the future.

f) As a comparison with similar companies regarding the results that have been achieved.

Hery states that the steps in analyzing financial statements are:

a) Collect financial data and supporting data required for one period or several periods.

b) Perform measurements or calculations by entering the numbers in the financial report into the formulas.

c) Provide interpretation of the results of calculations and measurements that have been carried out.

d) Creating a report on the results of the analysis.

e) Provide recommendations.

Methods of analysis of financial statements that are often used are:

a) Vertical analysis (vertical analysis) is an analysis that is carried out only for a period of financial statements, describing the relationship between financial statement items or conditions for one period only so that we cannot know the development of the company's condition from one period to the next.

b) Horizontal analysis (horizontal analysis) is an analysis performed by comparing financial statements from several periods.

\subsection{Financial Ratio}

Hery states that in practice there are at least 5 (five) types of financial ratios used to assess the company's financial condition and performance. The five types of financial ratios are:

a) Liquidity Ratio, is a ratio that describes the company's ability to pay its short-term obligations. Liquidity ratios are required for the purposes of credit analysis or financial ratio analysis. Liquidity ratios consist of:

1) The cash ratio is a method used to measure how much cash or cash equivalent is available to pay off short-term debt. 
2) Current Ratio, is the ratio used to measure the company's ability to pay short-term obligations or debts that are due immediately using available current assets.

3) quick Ratio Is a ratio that measures the company's ability to pay short-term liabilities using very current assets (cash + short-term securities + receivables), without using merchandise inventory or other current assets, equipment, prepaid expenses).

b) Capital Structure Ratio or Levarage Ratiois a ratio that describes the company's ability to pay all of its obligations. As with liquidity ratios, solvency ratios are also needed for credit analysis or financial risk analysis. The solvency ratio consists of: Debt Ratio, Debt to Equity Ratio, Long Term Debt to Equity Ratio, Times Interest Earned Ratio, Operating Income to Liabilities Ratio.

c) Activity ratio, is a ratio to measure the efficiency of the company's resources. The types of activity ratios: a) Turnover Receivables (Receivable Turn over). b) Day Average Billing Accounts Receivable (Days of Receivable). c) Turnover preparations (Inventory turn over). d) Day Average Billing preparations (Days of Inventory). e) Turnover Working Capital (Working Capital Turn over). f) Turnover of Fixed Assets (Fixed Assets Turn over). g) Asset Turnover (Total Assets Turn over).

d) Profitability Ratio Is the ratio of assessing the ability of the company to seek profit in a particular period. The types of profitability ratios: a) Profit Margin (Profit Margin on Sales). b) Return on Investment (ROI). c) Return on Equity (ROE). d) Earnings Per Share. The common-size analysis focuses attention to the distribution of funding between current liabilities, non-current liabilities and equity, and also focuses attention to the distribution of asset composition between current and non-current assets in the analysis of financial position. Trend analysis is used to determine the development of the performance of plantation companies listed on the IDX for the 2017-2019 period. For a description of the trend of certain ratio numbers, it can be obtained a description of the ups and downs or whether these ratios are constant.

\section{Research Method}

\subsection{Object of Research}

The research object used in this research is plantation companies listed on the Indonesian stock exchange 2017-2019. These companies are Golden Plantation Tbk, Austindo Nusantara Jaya Tbk, Bumi Teknokultura Unggul Tbk, Dharma Satya Nusantara Tbk, Eagle High Plantation Tbk, Grozco Plantation Tbk, Jaya Agra Wattie Tbk, PP London Sumatra Indonesia Tbk, Provident Agro Tbk, Salim Ivomas Pratama Tbk, Sawit Sumbermas Sarana Tbk, Sinar mas Agro Resources and technology Tbk, Astra Agro lestari Tbk, Bakrie Sumatra Plantations Tbk, Sampoerna Agro Tbk.

\subsection{Data Sources and Data Types}

\section{a) Data Sources}

The data in this research uses secondary data obtained from the Indonesia Stock Exchange from 2017 to 2019 in the form of plantation company financial reports. 


\section{b) Type of Data}

The data used in this research is quantitative data derived from the financial statements of plantation companies listed on the IDX from 2017 to 2019.

\subsection{Data Collection Technique}

Data collection technique that used in this Research is Documentation. Documents can be in the form of writings, pictures, or monumental works of a person. The data used from the documentation techniques in this study are the financial statements of plantation companies listed on the IDX from 2017 to 2019.

\subsection{Data Analysis Technique}

The data analysis method used in this research is quantitative analysis. The steps used in this research are [7]:

From the data collected, the researcher analyzes financial ratios.

Ratio Analysis, the ratio analysis in this study includes the ratio of liquidity, solvency, activity, and profitability as follows;

a) Liquidity Ratio

The liquidity ratio in this study includes the current ratio, the very current ratio or the quick ratio, and the cash ratio with the following analysis: Current ratio, shows the relationship between current assets and current liabilities of the company. The current ratio of health standards is twice as much. Standard health current ratio is $50 \%$.

b) Solvency Ratio

To measure the solvency ratio, use the debt ratio. Debt Ratio (Debt Ratio) describes the extent to which the company's capital can cover all company liabilities. This ratio is intended to determine the use of own capital to guarantee the amount of debt. The health standard debt ratio is $35 \%$.

c) Activity Ratio

Using the Accounts Receivable Turn Over ratio, is a ratio used to measure how long it takes to collect accounts receivable or how many times the funds embedded in trade receivables will rotate in one period. The health standard for Turn Over Accounts Receivable is 15 times.

d) Profitability Ratio

Is a ratio used to measure a company's ability to generate profits from its normal business activities. The measurement of the profitability ratio can be done by comparing the various components in the income statement and / or balance sheet. The health standard of Return on Assets is $30 \%$

e) The researcher conducted a trend analysis with the following calculations: Trend analysis is used to determine the development of the performance of plantation companies listed on the IDX for the 2017-2019 period. For a description of the trend of certain ratio numbers, it can be obtained a description of the ups and downs or whether these ratios are constant. So that the problems facing the company can be detected

The formulas that can be used are as follows:

Index number $=($ comparison year: base year $) \times 100$ 
f) Common-size analysis focuses on the distribution of funding between current liabilities, non-current liabilities and equity, and focuses on the distribution of asset composition between current and non-current assets in the analysis of financial position. The formula for calculating common-size analysis using financial position is as follows:

Financial Position $=($ Asset items: Total Assets $)$ x 100\%

g) Make comparisons with the calculation results that have been obtained from several companies. The methods used for comparison are: 1.Time series analysis, which is to compare over time or between periods, with the aim that later it will be seen graphically. 2 . Cross Sectional Approach, which is making comparisons to the results of the calculation of ratios that have been made between one company and another within a similar scope which is carried out simultaneously.

h) Interpretation stage of each calculated financial ratio analysis.

\section{Research Result}

\subsection{Liquidity Ratio Analysis}

The standard current ratio is 2 times. The current ratio value is two, meaning that the company has current assets whose value is twice the debt that must be paid. The current ratio of two is considered good enough for the company because it is considered safe for the short term. Based on Figure.1 it can be concluded the results of calculating the current ratio of the financial statements for 2017-2019 show that the healthiest current ratio value occurred in 2019, namely at PT Provident Agro Tbk amounting to 13.34 because that year the company received payment of accounts. And the most unhealthy current ratio occurred in 2018 at PT Gozco Plantations Tbk amounting to 0.13 because that year the company paid off its shortterm debt.

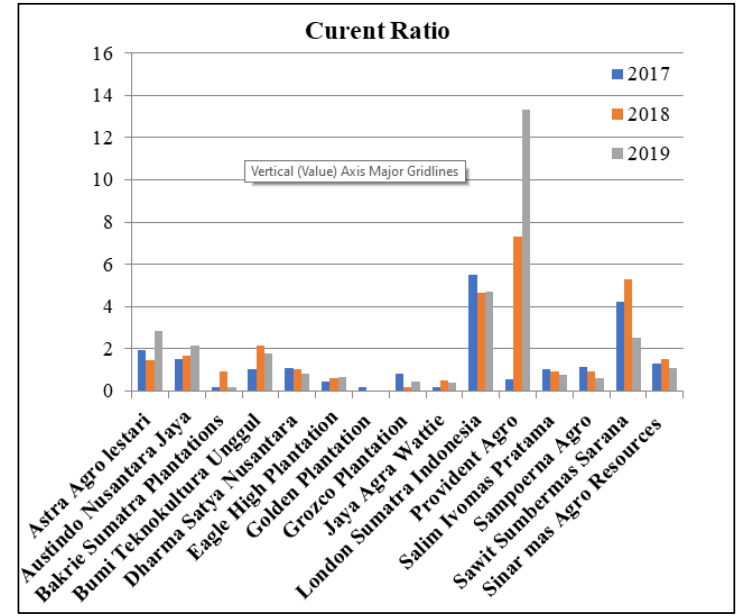

Fig. 1. Curent Ratio Plantation Sub-Sector Companies 2017-2019

\subsection{Solvency Ratio Analysis}

Based on Figure.2. The results of calculating the Debt Ratio (Debt Ratio) for 2017-2019 show that the company that has the best Debt Ratio is PT Provident Agro Tbk in 2019 at 0.34 . 
This means that the company's assets financed from debt sources are very small. And the one with the most unhealthy debt ratio is PT Bakrie Sumatra Unggul Tbk in 2019, amounting to $106.34 \%$, this means that all assets in the company are financed from debt sources.

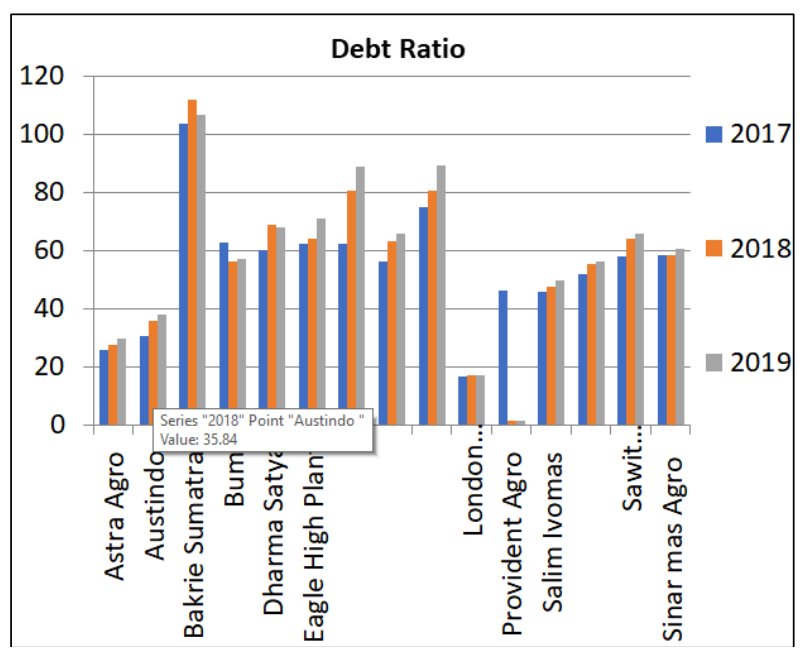

Fig. 2. Debt Ratio Plantation Sub-Sector Companies 2017-2019

\subsection{Activity Ratio}

Based on Figure.3. The activity ratio used in this study is the accounts receivable turnover ratio. Accounts Receivable TurnOver, is a ratio used to measure how long it takes to collect accounts receivable or how many times the funds embedded in trade receivables will rotate in one period. Accounts receivable turnover is 15 times standard. The formula used in calculating accounts receivable turnover is:

\section{Accounts Receivable Turnover $=$ Credit Sales: Average Accounts Receivable}

The results of the calculation produce the healthiest accounts receivable turnover ratio at PT Gozco Plantations Tbk as much as 339 times. And the most unhealthy trade receivable turnover ratio is PT Provident Agro Tbk, which only rotates 0.93 times.

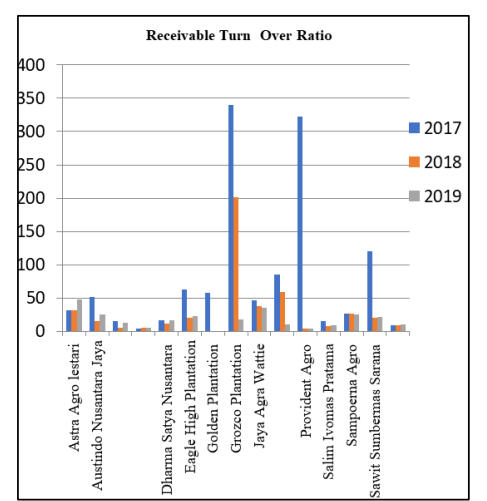

Fig. 3. Accounts Receivable Turnover Ratio Sub-Sector Companies 2017-2019 


\subsection{Profitability Ratio Analysis}

Profitability ratio is the ratio used to measure the company's ability to generate profits from its normal business activities. The measurement of the profitability ratio can be done by comparing the various components in the income statement and / or balance sheet. To measure the profitability of the company, researchers used the ratio of return on investment (return on assets). The rate of return on investment (return on assets) is the ratio used to assess financial compensation for the use of assets or equity against net income (profit after interest and taxes). The standard return on assets (return on assets) is as much as $30 \%$.

Based on Figure. 4 it can be concluded The results of the calculation show that PT Astra Agro Lestari Tbk has the highest rate of return on assets of $8.24 \%$ in 2017. Because in that year its sales level increased. Meanwhile, the lowest ROA level was at PT Gozco Plantations Tbk in 2019, because in that year the company's sales using all its assets were not maximized so that the ROA value was far below standard.

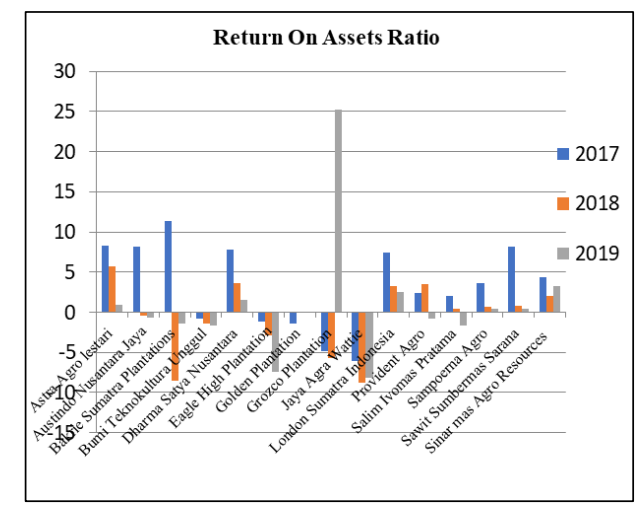

Fig. 4. Return on assets ratio Sub-Sector Companies 2017-2019

\subsection{Common Size Analysis and Trend Analysis}

Common size analysis and trend analysis are used to determine the performance development of plantation companies listed on the IDX for the 2017-2019 period. From the description of the trend of certain ratio figures, it can be obtained a description of the rise and fall of these ratios or not. So that the problems facing the company can be detected.

The formula used for trend analysis is as follows:

Index number $=($ comparison year: base year $) \times 100 \%$

Based on Figure.5 and table.1 it can be concluded Calculation results from 2017-2019 state that most plantation companies listed on the Indonesian stock exchange in 2017-2019 have a good common size rate, only a few have a low common size, including Grozco Plantation which only has a common size level of 0.03 in 2019 then Bakrie Sumatra Plantations in 2019 which has a common size value of 0.7. Then also Provident Agro in 2019 which has a common size of 0.34 .

The results of the trend analysis for the position of the financial statements for 2017-2019 show that almost all companies experience an increasing trend every year, the highest is PT Dharma Satya Nusantara in 2019 amounting to 129.62 because it is seen from current assets, non-current assets, liabilities and equity. the highest increment value. The results of the 
analysis of the trend in the position of the lowest financial statements are PT Provident Agro Tbk, which has a trend of 0.29 in 2019, then PT Grozco Plantation Tbk in 2019 at 45.36 because it is seen from current assets, non-current assets, liabilities and equity. has the lowest increment value.

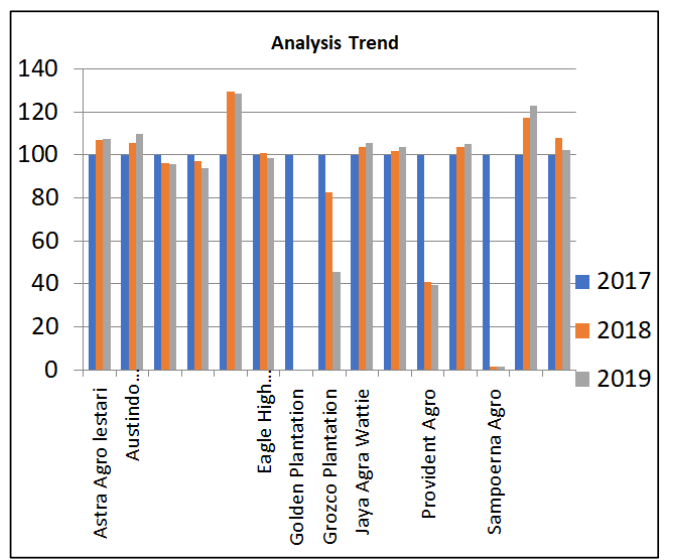

Fig. 5. Analysis trend Sub-Sector Companies 2017-2019

Table 1. Common Size Rate Sub-Sector Companies 2017-2019

\begin{tabular}{|c|c|c|c|c|c|c|c|}
\hline \multirow{3}{*}{$=$} & & \multicolumn{6}{|c|}{ ANALISIS COMMON SIZE } \\
\hline & & \multicolumn{2}{|l|}{2017} & \multicolumn{2}{|l|}{2018} & \multicolumn{2}{|l|}{2019} \\
\hline & & & $\%$ & & $\%$ & & $\%$ \\
\hline \multirow{5}{*}{1} & $\begin{array}{c}\text { Astra Agro } \\
\text { lestari }\end{array}$ & & & & & & \\
\hline & total aset & 25.119 .609 & 100 & 26.856 .967 & 100 & 26.974 .124 & 100 \\
\hline & total & & & & & & \\
\hline & $\begin{array}{l}\text { liabilitas } \\
\text { total ekvuitas }\end{array}$ & $\begin{array}{r}0.407 .132 \\
18.712 .477 \\
\end{array}$ & \begin{tabular}{|l|l|}
25,51 \\
74,49
\end{tabular} & $\begin{array}{r}1.382 .442 \\
19.474 .522\end{array}$ & $\frac{27,49}{72,51}$ & $\begin{array}{r}1.993 .591 \\
18.978 .527\end{array}$ & $\frac{29,64}{70,36}$ \\
\hline & $\begin{array}{l}\text { total } \\
\text { liabilitas dan } \\
\text { ekuitas }\end{array}$ & 25.119 .609 & 100 & 26.856 .967 & 100 & 26.974 .124 & 100 \\
\hline \multirow{6}{*}{2} & $\begin{array}{l}\text { Austindo } \\
\text { Nusantara } \\
\text { Jaya } \\
\end{array}$ & & & & & & \\
\hline & total aset & 569.496 .173 & 100,00 & 602.204 .916 & 100 & 625.708 .104 & 100 \\
\hline & $\begin{array}{l}\text { total } \\
\text { liabilitas }\end{array}$ & 174.141 .753 & 30,58 & 215.815 .703 & 35,84 & 237.000 .043 & 37.88 \\
\hline & total ekuitas & 395.354 .420 & 69,42 & 386.389 .213 & $\frac{1,07}{64,16}$ & 388.708 .061 & 62,12 \\
\hline & total & & & & & & \\
\hline & $\begin{array}{l}\text { liabilitas dan } \\
\text { ekuitas }\end{array}$ & 569.496 .173 & 100 & 602.204 .916 & 100 & 625.708 .104 & 100 \\
\hline \multirow{6}{*}{3} & $\begin{array}{l}\text { Bakrie } \\
\text { Sumatra } \\
\text { Plantations }\end{array}$ & & & & & & \\
\hline & total aset & 13.883 .992 & 100,00 & 13.363 .483 & 100 & 13.265 .645 & 100 \\
\hline & total & & & & & & \\
\hline & $\begin{array}{l}\text { liabilitas } \\
\text { total ekuitas }\end{array}$ & $\begin{array}{r}14.352 .436 \\
-468.445\end{array}$ & $\begin{array}{r}\frac{103,37}{-3,37} \\
\end{array}$ & $\begin{array}{r}14.798 .193 \\
-1.434 .710\end{array}$ & $\frac{110,74}{-10,74}$ & $\begin{array}{r}14.210 .485 \\
-944.840\end{array}$ & $\begin{array}{r}\frac{107,12}{-7,12} \\
-\frac{1}{4}\end{array}$ \\
\hline & & & & & & & \\
\hline & $\begin{array}{l}\text { liabilitas dan } \\
\text { ekuitas }\end{array}$ & 13.883 .991 & 100 & 13.363 .483 & 100 & 13.265 .645 & 100 \\
\hline \multirow{6}{*}{4} & $\begin{array}{l}\text { Bumi } \\
\text { Teknokuhtura } \\
\text { Unggul }\end{array}$ & & & & & & \\
\hline & total aset & 5.306 .055 .112 .389 & 100 & 5.165 .236 .468 .706 & 100 & 4.975 .248 .130 .342 & 100 \\
\hline & total & & & & & & \\
\hline & liabilitas & 3.318 .435 .703 .361 & 62,54 & 2.904 .707 .799 .328 & 56,24 & 2.832 .632 .209 .365 & 56,93 \\
\hline & total ekuitas & 1.987 .619 .409 .028 & 37,46 & 2.260 .528 .669 .378 & 43,76 & 2.142 .615 .920 .977 & 43,07 \\
\hline & $\begin{array}{l}\text { total } \\
\text { liabilitas dan } \\
\text { elkuitas }\end{array}$ & 5.306 .055 .112 .389 & 100 & 5.165 .236 .468 .706 & 100 & 4.975 .248 .130 .342 & 100 \\
\hline
\end{tabular}




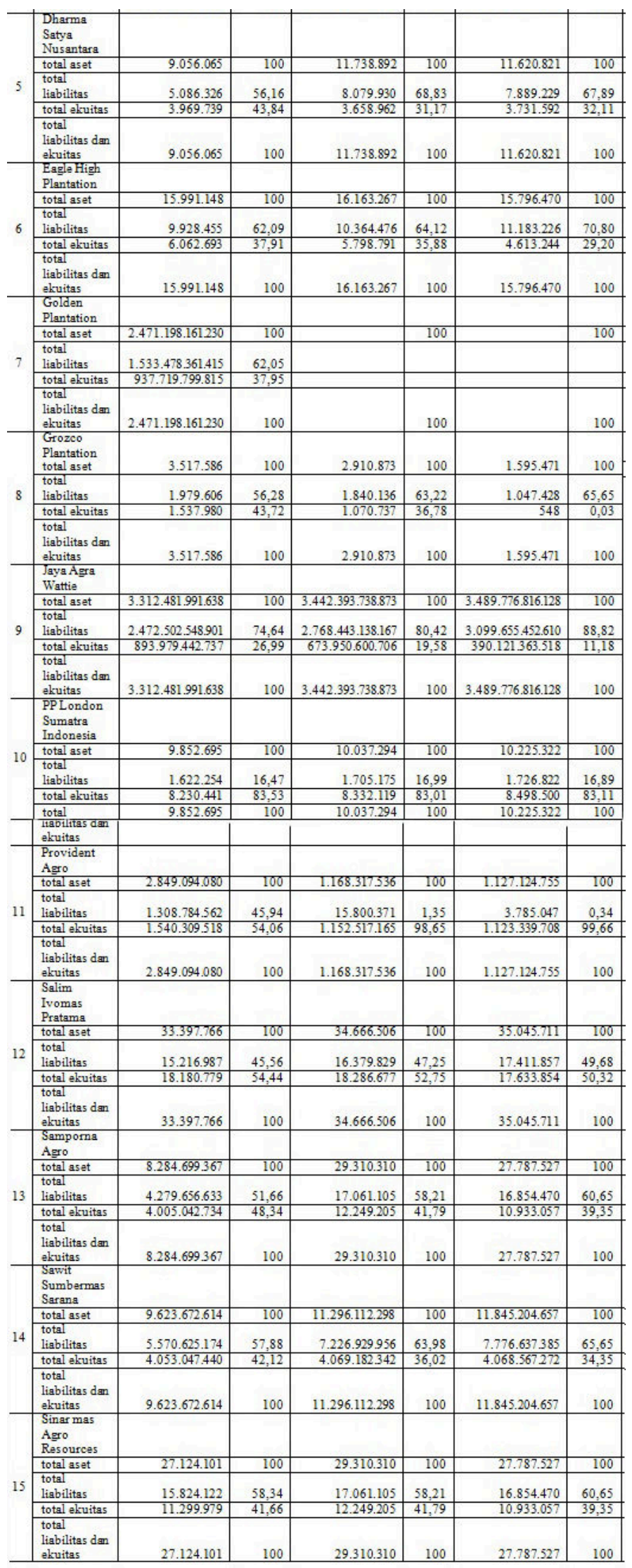




\section{Conclusion}

The conclusions that can be obtained based on the results of the discussion of this research are as follows:

a) The results of the analysis of the financial ratios of plantation companies listed on the IDX in 2017-2019 allow liquidation levels using the current ratio, some are in the good category and some are in the bad category. Most of the debt ratio analysis is in the poor category and only as good as the small ones are in the good category. Accounts receivable turnover analysis as good as possible is in the good category. The results of the analysis of trends in the financial statements for 2017-2019 show that almost all companies experience an increasing trend every year. The results of the analysis of the general size of the plantation companies listed on the IDX 2017-2019 mostly have a good level of similarity and only a few have a low level of similarity in size,

b) The company can improve its financial performance by increasing the liquidity (current ratio), reducing the debt ratio (debt to equity ratio). For management, in order to increase the company's profitability, the management must consider the composition of the composition of the Debt to Equity Ratio. Because this ratio can be used by investors as a consideration before investing in the company. Because these ratios are in optimal conditions, operational performance and profitability will increase.

\section{References}

[1] I. Fahmi, Analisis laporan Keuangan. Bandung: Alfabeta, 2018.

[2] K. R. dan J. J. W. Subramanyam, Analisis Laporan Keuangan., Edisi 10 b. Jakarta :Salemba Empat, 2013.

[3] S. N. Anggraeny, A. Kudhori, and T. Lestariningsih, 'Analisis Kinerja Keuangan dan Alokasi Belanja Modal Pemerintah Daerah', J. AKSI (Akuntansi dan Sist. Informasi), vol. 1, pp. 28-35, 2017.

[4] A. T. Putranto, 'Analisis laporan Keuangan Untuk Menilai Kinerja Keuangan PT. Mayora Indah Tbk Tangerang', J. Sekuritas (Ekonomi,Keuangan dan Investasi), vol. Vol. 1, no. No. 3, p. Hal 1-26, 2018.

[5] R. Istiarti, 'Analisis Kinerja Keuangan Perusahaan Perkebunan Kelapa Sawit Go Public di Indonesia 9kasus PT Astra Agro Lestari Tbk, PT Sampoerna Agro Tbk, PT PP London Sumatera Indonesia Tbk, PT Tunas Lampung Baru Tbk, dan PT Sinar Mas Agro Resources and Technology Tbk', BogorDepartemen Agribisnis, Fak. Ekon. dan Manajemen, Ist. Pertan. Bogor, 2014.

[6] Hery, Akuntansi Pengantar I, P.13. Jakarta.: Bumi Aksara., 2014.

[7] Sugiyono, Metode Penelitian Pendekatan Kuantitatif, Kualitatif, dan R\&D. Bandung: Alfabeta, 2014. 